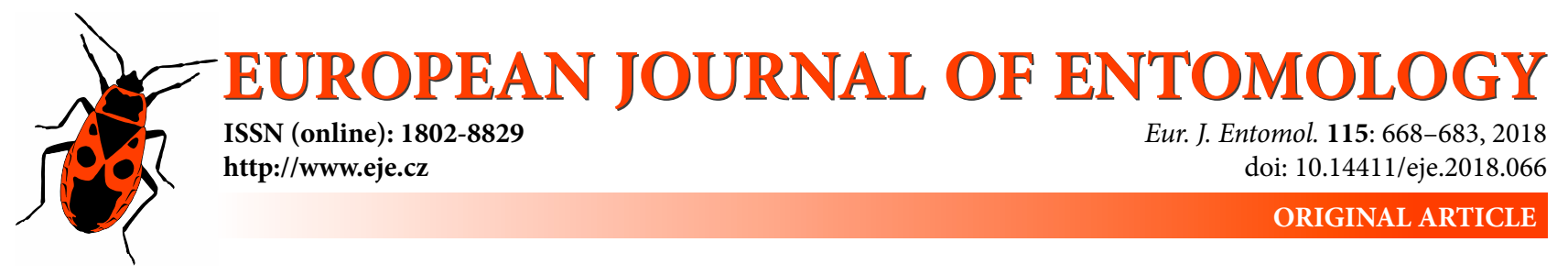

\title{
Afromuelleria, a new genus of Trachyphloeini from Limpopo, with descriptions of four new species (Coleoptera: Curculionidae: Entiminae)
}

\author{
ROMAN BOROVEC ${ }^{1}$ and JiŘi SKUHROVEC ${ }^{2, *}$ \\ ${ }^{1}$ Czech University of Life Sciences Prague, Faculty of Forestry and Wood Sciences, Department of Forest Protection and \\ Entomology, Kamýcká 1176, 16521 Praha 6 - Suchdol, Czech Republic; e-mail: romanborovec@mybox.cz \\ ${ }^{2}$ Group Function of Invertebrate and Plant Biodiversity in Agro-Ecosystems, Crop Research Institute, Drnovská 507, \\ 16106 Prague 6 - Ruzyně, Czech Republic; e-mail: jirislavskuhrovec@gmail.com
}

Key words. Coleoptera, Curculionidae, Entiminae, Trachyphloeini, Afromuelleria, taxonomy, new genus, new species, Afrotropical region, South Africa

\begin{abstract}
A new genus, Afromuelleria gen. n., assigned to the tribe Trachyphloeini Lacordaire, 1863, is described for four South African species of weevils: $A$. awelani sp. n., A. baobab sp. n., A. limpopo sp. n. and $A$. venda sp. n. All species are illustrated and keyed. Taxonomic status of the new genus is discussed and compared with similar genera of Trachyphloeini and Embrithini
\end{abstract} Marshall, 1942.

ZooBank Article LSID: 02D78E92-405C-4C8B-A670-ABC65E561AB6

\section{INTRODUCTION}

The Cape Floristic Region is by far the smallest in the world, characterized mainly by a very high species diversity of angiosperms, with about 8,700 species in 165 families, which is about $20 \%$ of all African angiosperms (Hendrych, 1984). The phytophagous superfamily of weevils (Curculionoidea), the largest superfamily of living organisms with about 62,000 described species (Oberprieler et al., 2007), should be very speciose in this botanically rich region, but at present, we know only a very small fragment of this weevil fauna. This is true also of the Entiminae Schoenherr, 1823, the largest weevil subfamily with about 12,000 described species (Oberprieler et al., 2007). First genera and species of South African entimines were described by Boheman (in Schoenherr, e.g., 1842, 1845) or Schoenherr (e.g., 1843, 1847) in Schoenherr's monumental monograph of world weevils. Continuation of this study based on material collected mainly during the first botanical expedition to South Africa (Gunn \& Codd, 1981) were descriptions by Fåhraeus (1871). The extensive work by G.A.K. Marshall, who published between 1902 and 1962 about 110 articles focused on Afrotropical and particularly South African weevils, contain descriptions of a number of genera and species of Curculionoidea, as well as several revisions providing keys. Additional studies were later published by Voss (e.g., 1959, 1974) and Oberprieler (e.g., 1988, 1995).

The majority of the genera and species of Entiminae so far described are floricolous and arboricolous taxa, which are easily available for study and most often collected. Small, terricolous, short-nosed weevils were almost entirely overlooked in the past, mainly due to the difficulty in collecting them, but also due to the lack of specialists focused on this very specific and speciose component of the fauna. Currently, there are a few species that were described by Boheman (in Schoenherr, e.g., 1842, 1845) and Fåhraeus (e.g., 1871). Several new species are described in articles with a broader focus by Marshall (e.g., 1923, 1955) or Voss (1974). The majority of these species were described in Palaearctic genera such as Trachyphloeus Germar, 1817 or Trachyphloeosoma Wollaston, 1869, only Schoenherr $(1842,1847)$ and Voss (1974) describe several South African genera of small terricolous entimine weevils. The first special works on this very poorly known specific fauna were published only recently, as revisions of already described genera (Borovec et al., 2009, 2014; Borovec \& Skuhrovec, 2018), or descriptions of new genera with new species (Borovec \& Meregalli, 2013; Borovec \& Oberprieler, 2013; Borovec \& Skuhrovec, 2017b).

\footnotetext{
* Corresponding author; e-mail: jirislavskuhrovec@gmail.com
} 
However, there is a lot of unidentified material collected mainly in recent decades and deposited in European as well as South African museums and private collections, mainly among unsorted material. The ratio of undescribed to described species is very high (Oberprieler et al., 2007) and many of the undescribed species belong also to undescribed genera. We describe herein a small genus including four species, known only from Limpopo province, which is easily distinguished from all other known genera not only by its external morphological characters (e.g., extremely short and wide rostrum) but also by unique characters of the males and unusual characters of female genitalia. We also discuss its taxonomic position and relation to other genera of small, terricolous entimines.

\section{MATERIAL AND METHODS}

Body length of all specimens was measured in dorsal view from the anterior border of the eyes to the apex of the elytra, excluding the rostrum. Width/length ratio of the rostrum was calculated using the maximum width at the base and maximum length to the base of the mandibles. Width/length ratios of pronotum, elytra, antennal segments and tarsomeres were based on the maximum width and length of the respective parts in dorsal view; length of onychium refers to the part protruding beyond the outline of tarsal segment 3. Dissected male and female genitalia were studied in glycerine. Female genitalia were afterwards embedded in Solakryl BMX (epoxy resin soluble in toluene; Medika, Prague); male genitalia were mounted dry on the same card as the respective specimen, with tegmen and sternite IX embedded in Solakryl BMX. Photographs of adults were taken with a Canon EOS 700D camera with an MP-E $65 \mathrm{~mm}$ macro lens and combined using Zerene Stacker and GIMP2 software. Details of adults (rostrum - dorsal and lateral view, protibia, ventrites) and genitalia were taken and enhanced using a HIROX RH-2000 digital microscope. The terminology used to describe the details of the rostrum, antenna and genitalia follows Oberprieler et al. (2014).

Exact label data of type specimens are cited: separate labels are indicated by a slash (/). Authors' remarks and comments are in square brackets.

Specimens are deposited in the following museums and private collections: NHMUK - Natural History Museum, London, United Kingdom (formerly British Museum of Natural History) (Maxwell Barclay); JSPC - Jiři Skuhrovec collection, Praha, Czech Republic; MMTI - Massimo Meregalli collection, Torino, Italy; BMSA - National Museum, Bloemfontein, South Africa (Burgert Muller); NMPC - National museum Praha, Czech Republic (Jiří Hájek); RBSC - Roman Borovec collection, Sloupno, Czech Republic; TMSA - Ditsong National Museum of Natural History (formerly Transvaal Museum), Pretoria, South Africa (Ruth Müller).

\section{TAXONOMY}

\section{Genus Afromuelleria gen. $\mathbf{n}$.}

Figs 1A-C, 7A-D, 8A-H, 9A-H, 10A-D, 11A-D, 12A-D

ZooBank taxon LSID:

6AA81AF2-37CB-4B3B-BB97-136D981FDF15

Type species. Afromuelleria awelani sp. n., here designated.

Diagnosis. Very small Entiminae, up to $2.1 \mathrm{~mm}$; rostrum extremely short and wide, at base as wide as head with eyes or wider, continuous with head; epifrons at base as wide as interocular space, with median longitudinal furrow; frons densely squamose; epistome very short, not projecting anteriorly; antennal scrobes in dorsal view visible along the whole length, in lateral view triangular, reaching above and below posterior margin of eye; eyes small, hardly projecting beyond the outline of head in dorsal view; head in ventral and lateral views partly finely densely longitudinally striate (striae well visible in glabrous transverse stripe); tibiae short and robust, amucronate, metatibiae without corbels; ventrite 1 in middle slightly shorter than ventrite 2 , suture between them distinctly sinuate; ventrites glabrous; tegmen with ring expanded into tegminal plate bearing elongated membraneous parameres; female sternite VIII with long and slender apodeme and small, widely oval, slightly wider than long plate, terminating at base of plate, plate with slender basal margin.

Description. Body length 1.5-2.1 mm. Integument of body brownish to blackish, legs and antennae unicolourous, reddish brown or brownish. Vestiture on body consists of dense appressed rounded scales; scales on elytra flat, 2 across one elytral interstria, leaving very slender glabrous striae; scales on pronotum slightly imbricate, with distinct deep puncture in centre. Antennal scapes, femora and tibiae covered with dispersed appressed scales with punctures in centres, with indistinct structure, funicles and tarsi without appressed scales; clubs finely and densely setose. Elytra covered with one dense mostly conspicuous regular row of semiappressed to erect, subspatulate to spatulate setae; pronotum and head with rostrum with similar, but shorter, densely irregularly scattered setae, rostrum moreover with regular row of these setae laterally projecting from outline and border its outline. Antennal scapes, femora and tibiae covered with slender, subspatulate, semierect setae; tarsi and funicles with short semierect bristles.

Rostrum (Figs 1B, C, 7B, C, 10B, C, 11B, C, 12B, C) extremely short and wide, $1.5-1.9 \times$ wider than long, widest at base or just before the base, evenly tapered apicad with straight or slightly rounded sides, apically widely rounded, at base as wide as head with eyes or wider, continuous with head; in lateral view weakly convex to almost flat, at the same level as head, anteriorly abruptly declivous beyond antennal insertion. Epifrons flat and wide, distinctly and evenly tapered apicad with straight sides, at base as wide as interocular space and evenly directly continuing posteriorly to posterior margins of eyes; space of epifrons with slender, median longitudinal furrow along the whole length, evanescent shortly before epistome and with shorter furrow very nearly parallel with margin of epifrons; when cleared of scales, shiny, smooth, regularly continuous with head, with long, fine and slender longitudinal ridges along the whole length, converging towards slender median furrow and multiplied by shorter and finer ridges on vertex. Frons not differentiated, densely squamose. Epistome small and very short, glabrous, posteriorly slightly carinated, hidden from above by a pair of large spatulate transverse scales. Mandibles not squamose, trisetose, weakly projecting anteriad. Prementum with a pair of long setae. Subgena (ventral part of rostrum) moderately densely covered by 

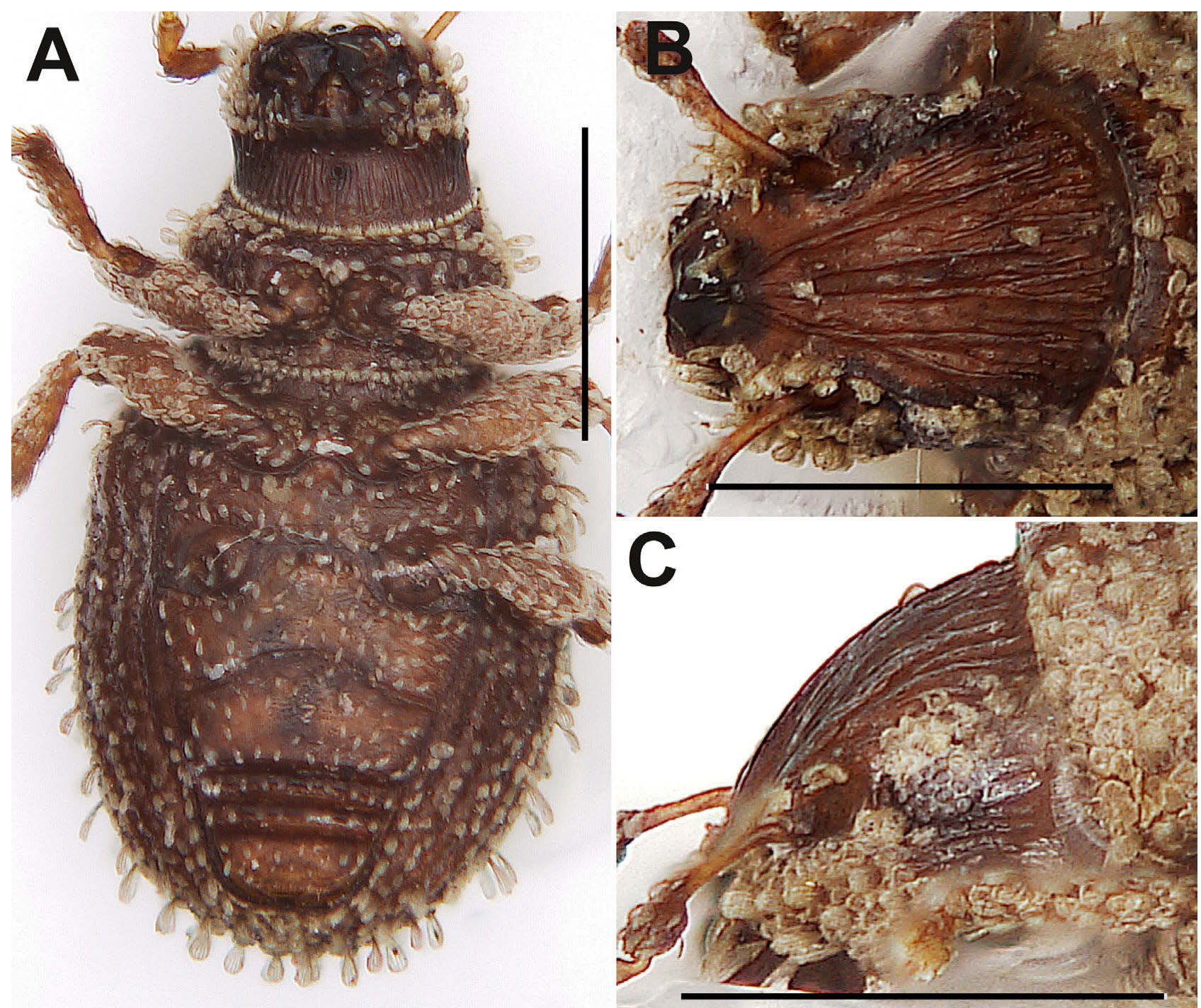

Fig. 1. Afromuelleria awelani sp. n. A - habitus, ventral view, male; B - rostrum without scales, dorsal view, male; C - rostrum without scales, lateral view, male. Scale bars: $0.5 \mathrm{~mm}$.

appressed subspatulate scales. Gena as long as subgena, glabrous, finely, densely, longitudinally striate; borderline between gena and subgena arched. Scrobes in dorsal view visible along the whole length as a narrow furrow, distinctly constricted in anterior third and then evenly enlarged posteriad, reaching base of rostrum before eyes; in lateral view short, slightly curved, triangular, sharply set off from densely squamose lateral part of rostrum, distinctly enlarged posteriad, reaching eye, with well defined edges and reaching posterior margin of eye, dorsal border aligned with dorsal border of eye, ventral border below eye, leaving slender glabrous furrow between it and eye. Head very wide and flat, with slender longitudinal stria in middle and next to borders, continuing into striae on epifrons. Eyes very small, convex, but not or only slightly projecting beyond outline in dorsal view, in lateral view subcircular, positioned approximately in the middle of head height. Head in lateral and ventral part with glabrous transverse stripe, finely densely longitudinally striate (except a subtriangular squamose spot in lateral view and a narrow anterior stripe in ventral view).
Antennae (Figs 7A, 10A, 11A, 12A) short and slender; scapes hardly reaching anterior border of pronotum, 1.2-1.4× longer than funicle, basal half very slender, curved at midlength, apical half distinctly enlarged, clavate, apex as wide as club; funicle 5-, 6- or 7-segmented; segment 1 conspicuously larger, distinctly longer and wider than other segments, faintly narrower than apex of scape; segment 2 longer than wide; segments 3-7 isodiametric to wider than long; club oval.

Pronotum (Figs 7A, 10A, 11A, 12A) short and wide, 1.5$1.8 \times$ wider than long, sides rounded, widest at midlength or before, behind anterior border slightly constricted with anterior border slightly narrower than posterior border; disc regularly convex without furrow or depression; base straight. Anterior border in lateral view straight, without ocular lobes or setae.

Procoxal cavities contiguous, round in middle of prosternum. Scutellar shield indistinct.

Elytra (Figs 7A, 10A, 11A, 12A) oval, 1.2-1.4× longer than wide, widest at midlength, sides rounded, apically widely rounded, with regularly rounded humeral calli; 


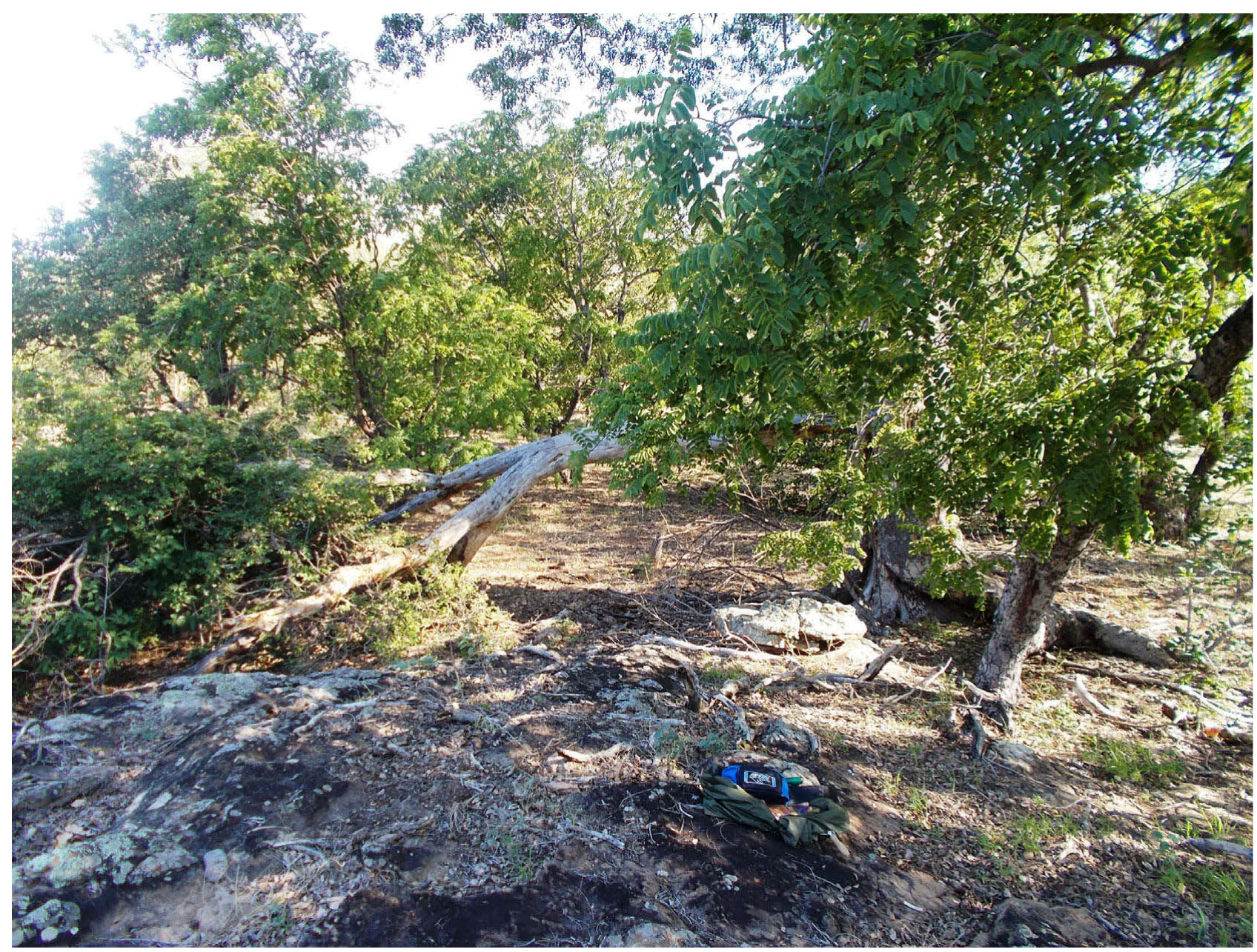

Fig. 2. Habitat of Afromuelleria awelani sp. n. Adults were sifted from forest litter in mopane type forest, below a big Ekebergia sp. (Meliaceae), in partly rocky terrain.

striae distinctly narrowly punctate, sometimes hidden under appressed scales; interstria flat; disc in lateral view slightly convex to almost flat, slope overhanging apex.

Tergite VII in males subtrapezoidal, translucent, with sclerotized narrow margins, apically concave; tergite VIII in males subsquare, weakly sclerotized. Tergite VII and VIII in females similar to those in males, more weakly sclerotized, slightly larger, tergite VII with convex apical margin.

Legs (Figs 7A, 10A, 11A, 12A) short and robust. Procoxae subglobular. Mesocoxae semiglobular, moderately widely separate, mesosternal process about as wide as half of diameter of mesocoxa, not reaching posterior margin of mesocoxae. Metacoxae shortly transverse, separated by about $1.5 \times$ their width. Femora faintly swollen, unarmed. Tibiae very short, without mucro, lateral margin straight, mesal margin indistinctly bisinuate; protibiae (Figs 7D, $10 \mathrm{D}, 11 \mathrm{D}, 12 \mathrm{D}) 3.2-3.8 \times$ longer than wide at apex, apex obliquely subtruncated with fringe of slender and moderately long, sparse, brownish to blackish bristles; meso- and metatibiae with moderately small apical surface, glabrous, fringed by long blackish bristles, laterally longer than mesally; metatibiae without corbels. Tarsi short, segment 2 wider than long, segment 3 bilobed and distinctly wider than segment 2, onychium 1.2-1.8 $\times$ longer than segment 3 ; basal half of claws solidly fused, apical half divaricate.

Abdomen ventrally longer than wide (Fig. 1A); middle of ventrite 1 slightly shortened, behind metacoxa about as long as ventrite 2 , ventrite $21.5 \times$ as long as ventrites 3 and 4 combined; ventrites 3 and 4 short, equally long; ventrite 5 subtrapezoidal, obtuse, equal in both sexes; suture between ventrites 1 and 2 distinctly sinuate, fine, other sutures wide, rough, straight; all ventrites glabrous, unpunctured, finely shagreened, sparsely covered with semiappressed spatulate scales. Metaventral process obtuse, slightly longer than transverse diameter of metacoxa.

Male terminalia. Penis (Figs 8A-D) moderately long, slender, differing between species in shape; temones short, as long as penis and longer than tegminal manubrium. Tegmen (Figs 8E-H) very exceptional in Entiminae, with tegminal plate; ring moderately small, enlarged at base of manubrium, which is short, longer than diameter of ring; ring incomplete, interrupted in middle, expanded to form a large membranous, not diversified tegminal plate, almost as long as diameter of ring, lateral edges slightly more sclerotized and elongate forming two differently long, slender, membraneous parameres, distant at base. Sternite IX with spiculum gastrale moderately long, anteriorly perpendicu- 


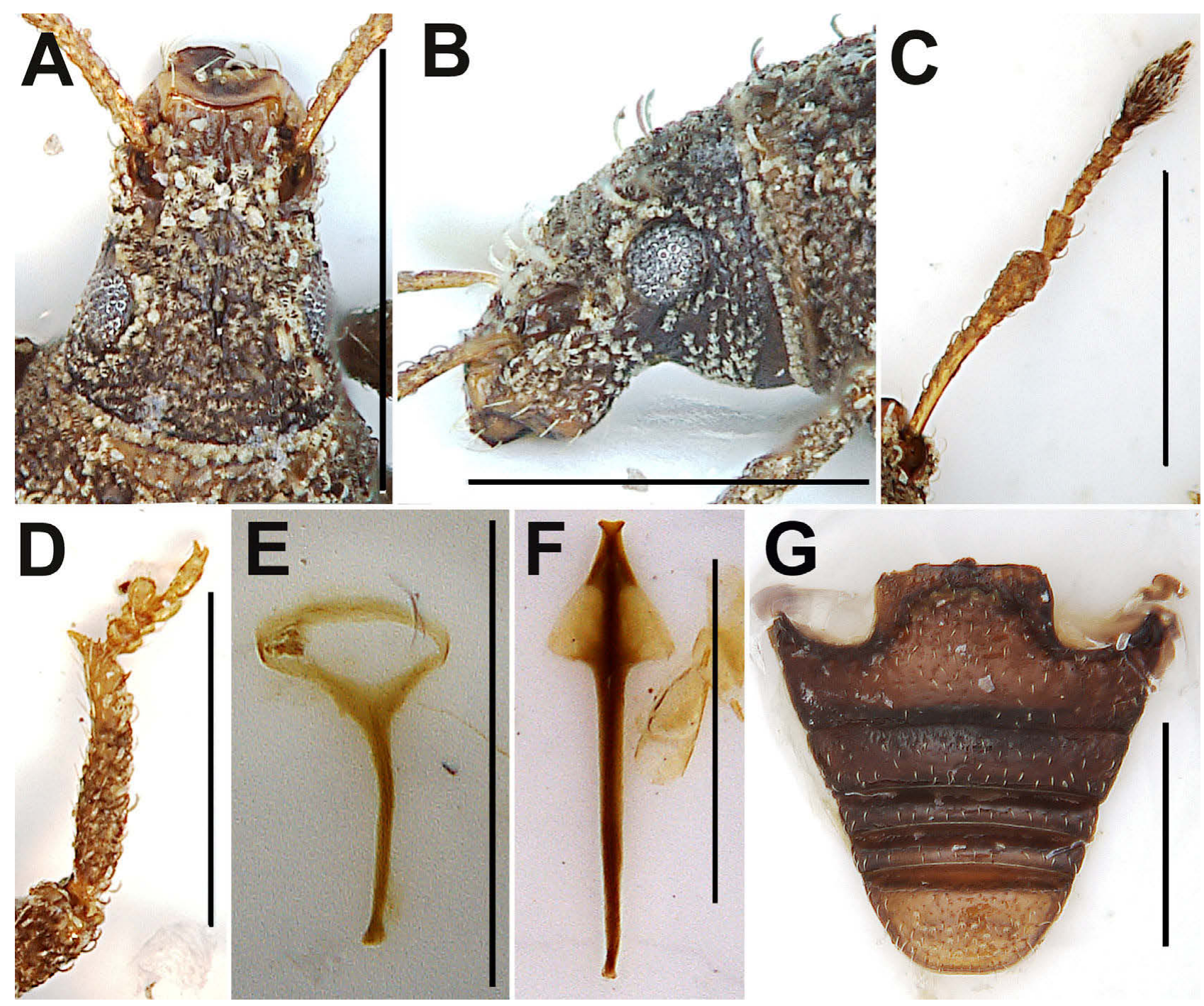

Fig. 3. Epistomius colonnellii Borovec \& Skuhrovec, 2017. A - rostrum, dorsal view, female; B - rostrum, lateral view, female; C - antenna, female; D - protibia, female; E - tegmen, male; F - sternite VIII, female; G - ventrites, female. Scale bars: $0.5 \mathrm{~mm}$.

larly curved and tapered, posteriorly with U-shaped basal plate.

Female terminalia. Sternite VIII (Figs 9A-C) with long and slender apodeme, 5.8-7.7 $\times$ longer than plate; plate small, oval, nearly isodiametric, with basal half slightly sclerotized, apical margin sparsely fringed with short and fine setae, apodeme terminates at base of plate, basal margin developed. Gonocoxites (Figs 9D, E) long and slender, subtriangular, weakly sclerotised, with slender and moderately long apical styli with apical setae. Spermatheca (Figs 9F-I) with slender, pointed, regularly curved cornu and short but differentiated ramus and nodulus, differing between species.

Sexual dimorphism. Not present. Sexes externally indistinguishable.

Derivation of name. This newly described genus is dedicated to our German colleague and friend, born in Angola and living in South Africa, Ruth Müller, curator of Ditsong National Museum of Natural History in Pretoria. She is extremely enthusiastic and keen about nature and has helped many specialists working on beetles in South Africa. Moreover, Ruth during many field trips collected a remarkable amount of important material for the mu- seum and science, for example, two of the four new species of this newly described genus.

Distribution. The genus contains four newly described species; all are known only from the northern part of Limpopo province in South Africa.

Biology. Afromuelleria awelani sp. n. was sifted from forest litter in mopane type forest, below a big Ekebergia sp. (Meliaceae), in partly rocky terrain (Fig. 2). Afromuelleria limpopo sp. n. was collected using ground traps baited with banana. Species of this genus seem to be inhabitants of forests, living in litter below trees in more humid habitats.

Taxonomical remarks. Afromuelleria gen. n. belongs to the tribe Trachyphloeini Lacordaire, 1863 based on the following morphological characters: rostrum wider than its length; scrobes located subdorsally, laterally directed towards eyes; epifrons with well defined margins along the whole length, at base as wide as the space between anterior eye margins; elytra without humeral calli, fused at suture; the entire dorsal part of body densely squamose and metatibiae lacking corbels. 


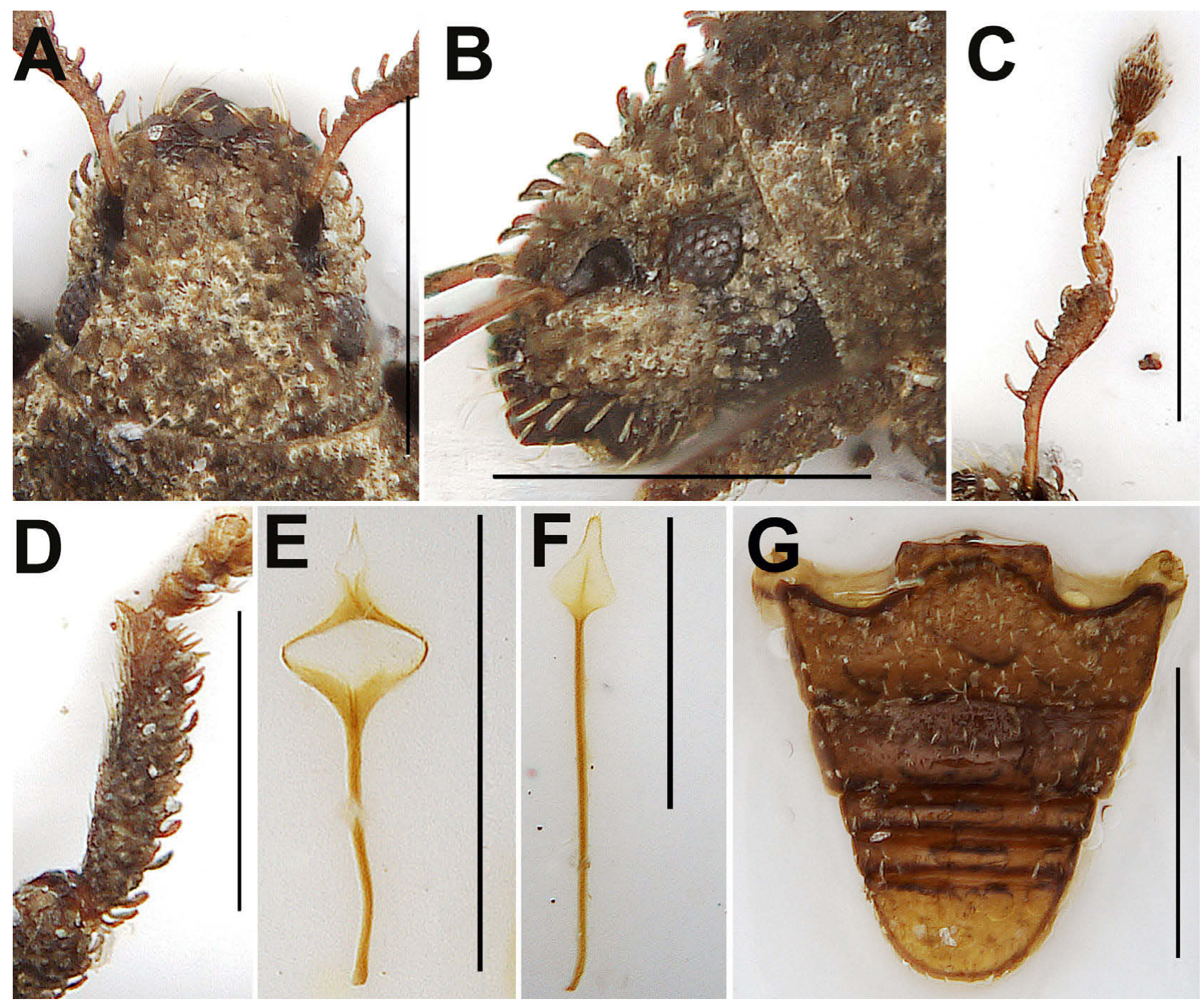

Fig. 4. "Trachyphloeosoma" brevicolle Voss, 1974. A - rostrum, dorsal view, male; B - rostrum, lateral view, male; C - antenna, male; D - protibia, male; E - tegmen, male; F - sternite VIII, female; G - ventrites, male. Scale bars: $0.5 \mathrm{~mm}$.

In the tribe Trachyphloeini, Afromuelleria gen. n. is very exceptional in having the following set of characters: rostrum extremely short and wide, at base as wide as head with eyes or wider, with regular row of spatulate setae; antennal scrobes in lateral view triangular, reaching posterior margin above and below the eyes; tibiae without mucro, tegmen with ring expanded into a tegminal plate elongated into membraneous parameres, and female sternite VIII with a slender and long apodeme, 5.8-7.7 $\times$ longer than small oval plate, terminating at slender basal margin. Among Trachyphloeini genera with connate claws, Afromuelleria gen. n. and Epistomius Borovec \& Skuhrovec, 2017 are the only genera with a rostrum continuous with their head, while the other Trachyphloeini genus with connate claws, Pentatrachyphloeus Voss, 1974, has rostrum clearly separated from the head by a slender transverse sulcus.

Afromuelleria gen. n. and Epistomius can be easily distinguished by the following characters:

Afromuelleria gen. n. Rostrum $1.5-1.9 \times$ wider than long (Figs 7B, 10B, 11B, 12B). Frons densely squamose, flat (Figs 7B, 10B, 11B, 12B). Epistome not projecting ante- riad (Figs 7B, 10B, 11B, 12B). Epifrons with straight sides (Figs 7B, 10B, 11B, 12B). Antennal scrobes in dorsal view visible along the whole length, in lateral view they reach the eyes (Figs 7B, 10B, 11B, 12B). Elytra not constricted behind base (Figs 7A, 10A, 11A, 12A). Tibiae short and robust, without a mucro; protibiae 3.2-3.8× longer than width at apex (Fig. 7A, D). Ventrites with conspicuous spatulate setae, ventrite 1 in middle slightly shorter than ventrite 2 , ventrite $2,1.5 \times$ as long as ventrites 3 and 4 combined (Fig. 1A). Suture between ventrites 1 and 2 distinctly sinuate, between 2-5 straight (Fig. 1A). Tegmen with ring extending to the tegminal plate (Figs $8 \mathrm{E}-\mathrm{H}$ ). Sternite VIII in females with apodeme $5.8-7.7 \times$ as long as a plate, ending at basal margin; plate small, oval, without apical process (Figs 9A-C). Spermatheca with differentiated nodulus and ramus (Figs 9F-H).

Epistomius Borovec \& Skuhrovec. Rostrum 1.1-1.3× wider than long (Figs 3A, B). Frons glabrous and deepened (Fig. 3A). Epistome projecting anteriorly and laterally forming sharp teeth directed dorsally (Fig. 3A). Epifrons with distinctly concave sides (Fig. 3A). Antennal scrobes 


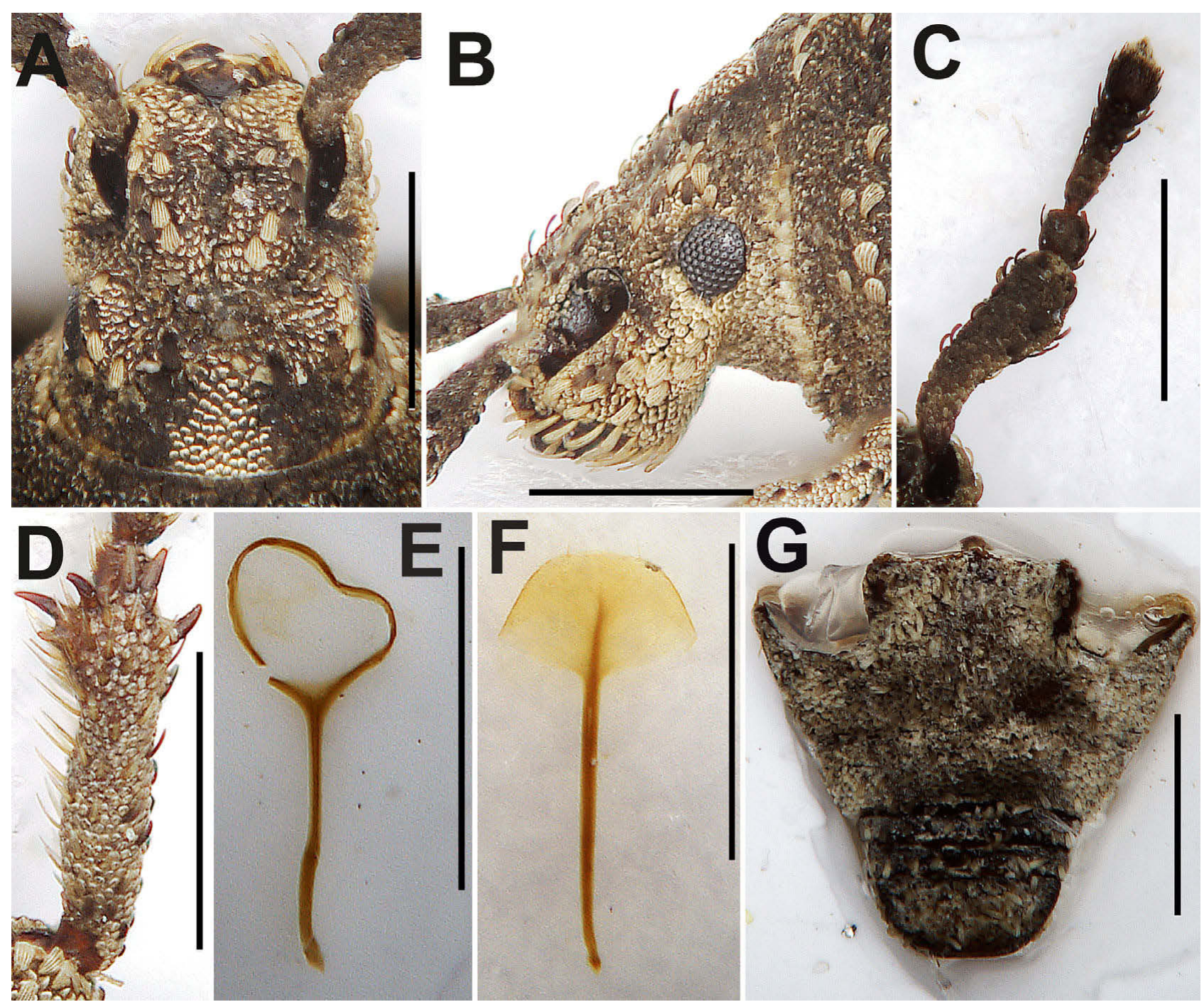

Fig. 5. Afrophloeus spathulatus (Boheman, 1842) (A-D, F), A. squamifer (Boheman, 1842) (E, G). A - rostrum, dorsal view, female; B rostrum, lateral view, female; C - antenna, female; D - protibia, female; E - tegmen, male; F - sternite VIII, female; G - ventrites, female. Scale bars: $0.5 \mathrm{~mm}$.

in dorsal view visible on anterior half of rostrum, in lateral view short, reaching about half the distance from antennal insertion to eyes (Figs 3A, B, C). Elytra behind base constricted. Tibiae long and slender, mucronate; protibiae 5.5-6.4 $\times$ longer than the width at midlength (Fig. 3D). Ventrites with inconspicuous fine piliform setae, ventrite 1 in middle slightly shorter than ventrites $2-4$ together, ventrite 2 in middle slightly longer than ventrites 3 or 4 (Fig. $3 \mathrm{G})$. Suture between ventrites 1 and 2 straight, between 2-5 weakly arched (Fig. 3G). Tegmen without a tegminal plate (Fig. 3E). Sternite VIII in females with apodeme 2.0$2.5 \times$ as long as a plate, terminating inside plate; plate triangular, apex with a Y-shaped process (Fig. 3F). Spermatheca without differentiated nodulus and ramus.

Among Trachyphloeini with free claws, Afromuelleria gen. $\mathrm{n}$. is only similar in general habitus (small size with extremely short and wide rostrum) to "Trachyphloeosoma" brevicolle Voss, 1974, known from the Western Cape (this species was described by Voss by mistake in his original description of the genus Trachyphloeosoma Wollaston, 1869, see Borovec \& Skuhrovec, 2017a). This species belongs to an undescribed genus including 14 undescribed species native primarily to Western Cape, Eastern Cape, but we also know two species from KwaZulu-Natal, (Borovec \& Skuhrovec, 2017a). Both genera share not only short and wide rostrum but also rostrum continuous with head, short and slender antennae, tegmen with parameres and female sternite VIII with long and slender apodeme. In having free claws "Trachyphloeosoma" brevicolle belongs to a group of species and genera related to Nama Borovec \& Meregalli, 2013, native to Western and Northern Cape and southern Namibia. "Trachyphloeosoma" brevicolle and its allies will be described in a forthcoming revision dedicated to all Trachyphloeini with free claws. However, both genera can be distinguished by the following characters:

Afromuelleria gen. n. Claws connate. Frons squamose (Figs 7B, 10B, 11B, 12B). Rostrum at base wider than head including eyes (Figs 7B, 10B, 11B, 12B). Antennal scrobes in lateral view reaching eyes (Figs 7C, 10C, 11C, 12C). Head and rostrum when cleared of scales shiny, deeply and densely longitudinally striate along the whole length (Figs $1 \mathrm{~B}, \mathrm{C})$. Pronotum in lateral part without projecting protu- 


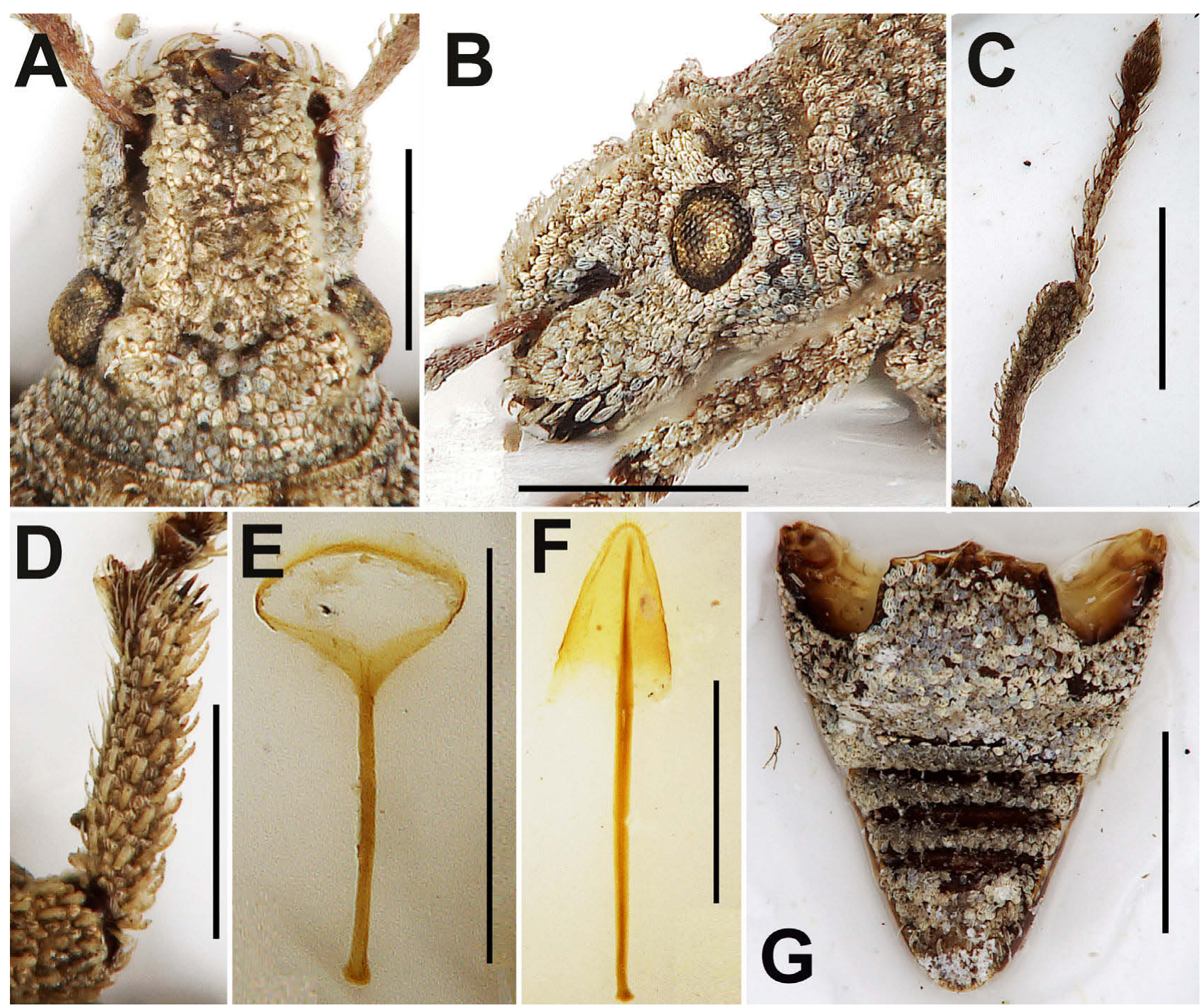

Fig. 6. Glyptosomus costipennis Schoenherr, 1847. A - rostrum, dorsal view, female; B - rostrum, lateral view, female; C - antenna, female; D - protibia, male; E - tegmen, male; F - sternite VIII, female; $G$ - ventrites, female. Scale bars: $0.5 \mathrm{~mm}$.

berances (Figs 7A, 10A, 11A, 12A). Tegmen with a tegminal plate (Figs $8 \mathrm{E}-\mathrm{H})$. Female sternite VIII with small, oval plate (Figs 9A-C).

"Trachyphloeosoma" brevicolle Voss and related species. Claws free. Frons glabrous (Fig. 4A). Rostrum at base narrower than head including eyes (Figs 4A, B). Antennal scrobes in lateral view separated from eyes by squamose stripe (Fig. 4B). Head and rostrum when cleared of scales, matt, densely finely irregularly punctate. Pronotum in lateral part with a different number of laterally projecting protuberances. Tegmen without a tegminal plate (Fig. 4E). Female sternite VIII with small, narrowly rhombus-shaped plate (Fig. 4E).

The presence of corbels on the metatibial apex is, in fact, the only character separating the Trachyphloeini and Embrithini Marshall, 1942. The mutual relationship between these two tribes is unclear at present because the separation of these two tribes is based on only one character, which appears to be unstable. This fact becomes more apparent when the fact that metatibial corbels have several different forms and could also be variable inside one tribe, for example, Oosomini Lacordaire, 1863, which currently contains genera with different forms of corbels and even genera lacking corbels. On the other hand, the very speciose genus Naupactus Dejean, 1821 (Naupactini Gistel, 1856) from South America even contains species with and without corbels (Del Río et al., 2018). Clarification of this situation is not a topic of the present paper, but it is the reason why we compare the newly described genus with the tribe Embrithini. It includes also small terricolous forms, although most are still undescribed. Except for the metatibiae, it is only possible to compare Afromuelleria gen. n. with two embrithine genera, Afrophloeus Borovec \& Oberprieler, 2013 and Glyptososmus Schoenherr, 1847, with which it shares mainly a densely squamose frons and short and robust protibiae. These two characters separate all three genera from other genera including small, terricolous entimines, such as Phaylomerinthus Schoenherr, 1842 and Lalagetes Schoenherr, 1842. Afromuelleria gen. n. can be easily distinguished from Afrophloeus Borovec \& Oberprieler by the following characters: 


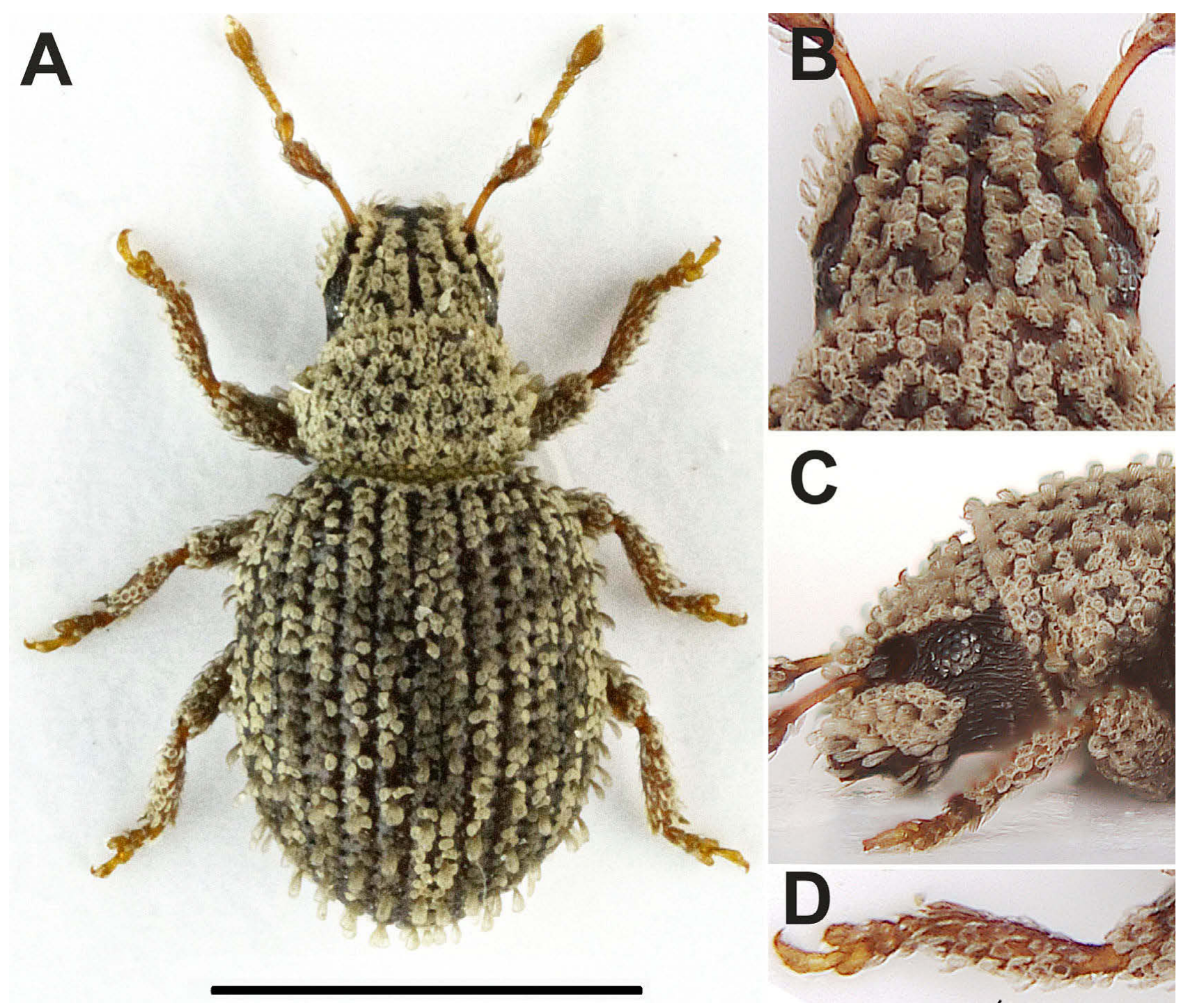

Fig. 7. Afromuelleria awelani sp. n. A - habitus, dorsal view, male; B - rostrum, male, dorsal view; C - rostrum, male, lateral view; D protibia, male. Scale bar: $1 \mathrm{~mm}$.

Afromuelleria gen. n. Epifrons wide, as wide as space between anterior margins of eyes (Figs 7B, 10B, 11B, 12B). Rostrum continuous with head (Figs 7B, 10B, 11B, 12B). Antennal scrobes in lateral view reach eyes (Figs 7C, $10 \mathrm{C}, 11 \mathrm{C}, 12 \mathrm{C})$. Antennae slender, funicle segments 3-7 isodiametric (Figs 7A, 10A, 11A, 12A). Protibiae fringed with equally sized bristles (Figs 7D, 10D, 11D, 12D). Metatibiae without corbel. Ventrites glabrous, ventrite 1 at middle slightly shorter than ventrite 2 (Fig. 1A). Tegmen with tegminal plate lengthened into parameres (Figs 8E-H). Female sternite VIII with apodeme terminating at basal margin of the small oval plate (Figs 9A-C).

Afrophloeus Borovec \& Oberprieler. Epifrons narrow, at base distinctly narrower than space between anterior margins of eyes (Fig. 5A). Rostrum separated from the head by transverse sulcus (Fig. 5A). Antennal scrobes in lateral view separated from eyes by squamose stripe (Fig. 5B). Antennae robust, funicle segments 3-7 distinctly wider than long (Fig. 5C). Protibiae armed with 7 sparse spines of different length and shape (Fig. 5D). Metatibiae with wide squamose corbel. Ventrites squamose, ventrite
1 at middle about as long as ventrites $2-4$ combined (Fig. $5 \mathrm{G}$ ). Tegmen without a tegminal plate and parameres (Fig. 5E). Female sternite VIII with apodeme terminating inside large, umbrella-shaped plate (Fig. 5F).

Afromuelleria gen. n. and Glyptososmus can be easily distinguished by the following characters:

Afromuelleria gen. n. Rostrum continuous with the head (Figs 7B, 10B, 11B, 12B). Tibiae amucronate. Metatibiae without corbel. Abdominal ventrite 1 in middle slightly shorter than ventrite 2 (Fig. 1A). Suture between ventrites 1 and 2 distinctly sinuate (Fig. 1A). Tegmen incomplete expanded into a large membraneous tegminal plate with parameres (Figs 8E-H). Female sternite VIII with long apodeme, 5.8-7.7 $\times$ longer than plate; plate small, oval, apodeme terminating at the slender basal margin (Figs 9A-C).

Glyptosomus Schoenherr. Rostrum distinctly separated from the head by narrow, well-edged, V-shaped stria (Figs 6A, B). Tibia mucronated (Fig. 6D). Metatibiae with squamose corbel. Abdominal ventrite 1 in middle somewhat longer than ventrites 2-4 combined (Fig. 6G). Suture be- 


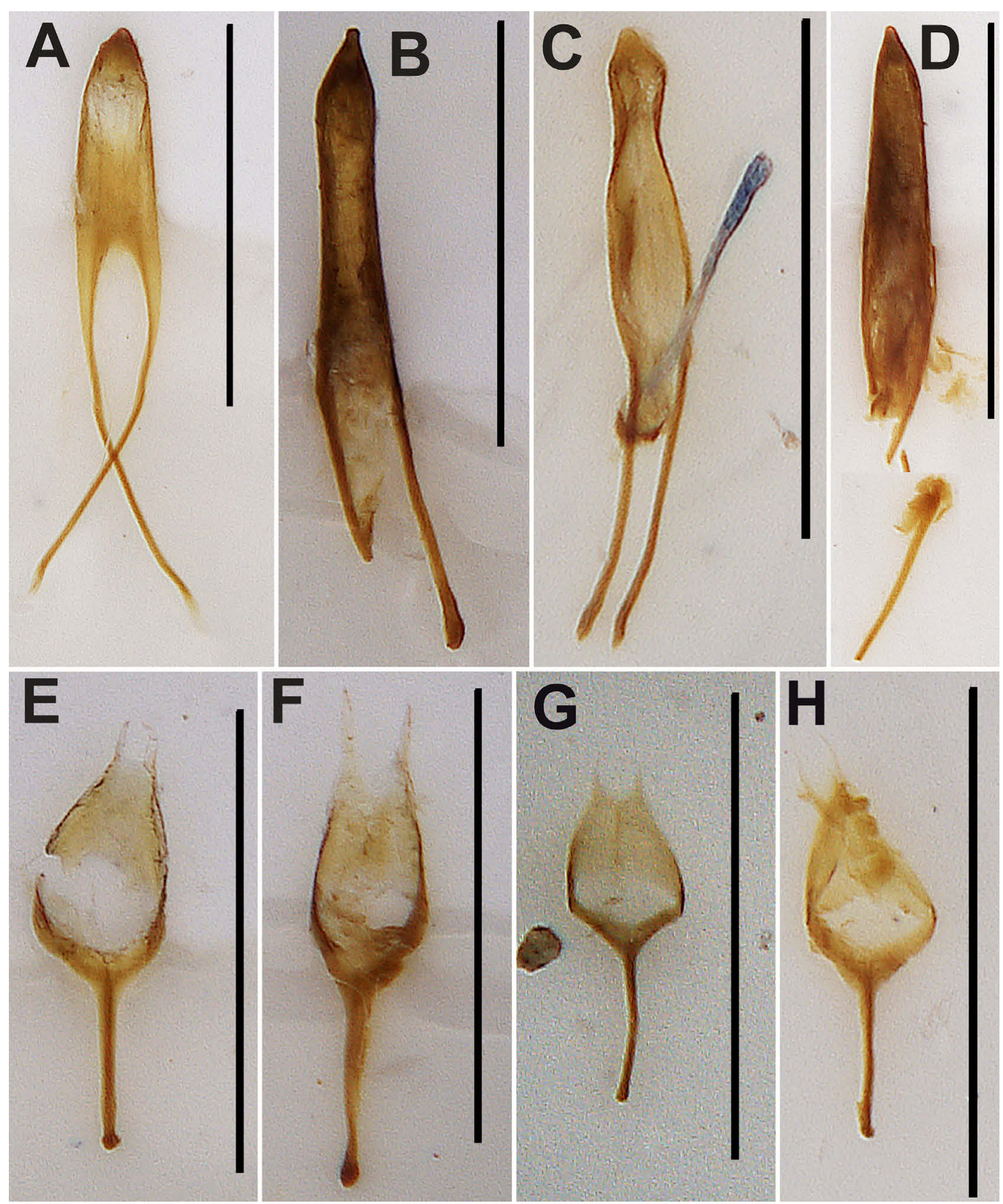

Fig. 8. Males terminalia. Aedeagus: A - A. awelani sp. n.; B - A. baobab sp. n.; C - A. limpopo sp. n.; D - A. venda sp. n.; and tegmen: $\mathrm{E}-$ A. awelani sp. n.; F - A. baobab sp. n.; G - A. limpopo sp. n.; H - A. venda sp. n. Scale bars: $0.5 \mathrm{~mm}$.

tween ventrites 1 and 2 arched (Fig. 6G). Tegmen with a slender complete ring but without parameres (Fig. $6 \mathrm{E}$ ). Female sternite VIII with apodeme 1.9-2.7× longer than the plate, terminating just inside plate, plate umbrella-shaped, with basal margin ill-defined (Fig. 6F).

\section{Afromuelleria awelani sp. $\mathbf{n}$.}

Figs 1A-C, 7A-D, 8A, E, 9A, D, F

ZooBank taxon LSID:

A5FC4477-BAFD-453A-BE6C-1FE4A09AFD37

Differential diagnosis. A. awelani sp. n. differs from all other species in this genus by its rostrum being wider 

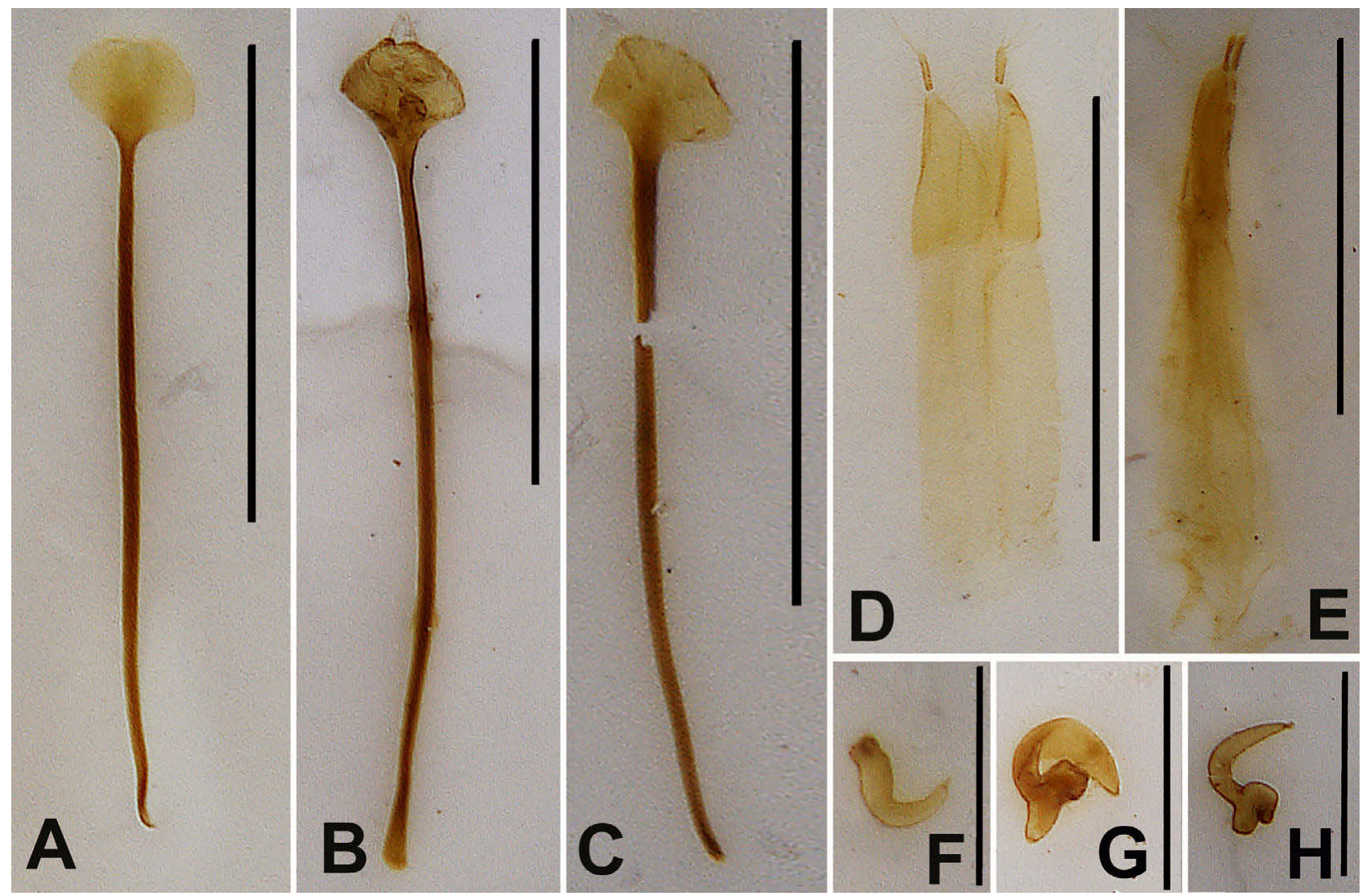

Fig. 9. Females terminalia. Sternite VIII: A - A. awelani sp. n.; B - A. baobab sp. n.; C - A. limpopo sp. n.; gonocoxite: D - A. awelani sp. n.; E - A. baobab sp. n.; and spermatheca: F - A. awelani sp. n.; G - A. baobab sp. n.; I - A. limpopo sp. n. Scale bars: $0.5 \mathrm{~mm}$ (A-E) and $0.25 \mathrm{~mm}(\mathrm{~F}-\mathrm{H})$.

shortly before base. In having a 7-segmented funicle, it is similar only to $A$. baobab sp. n., but is distinguishable from it by having a penis with short pointed tip and spermatheca with equally long and wide ramus and nodulus.

Description. Body length 1.59-1.84 mm, holotype 1.63 $\mathrm{mm}$. Elytra with conspicuous row of spatulate, semierect setae, slightly longer than half the width of one interstria.

Rostrum (Figs 1B, C, 7B, C) 1.88-2.03 $\times$ wider than long, short basal part enlarged anteriad, then evenly tapered apicad with straight sides, at base wider than head with eyes; eyes hardly projecting beyond outline in dorsal view.

Funicle 7-segmented (Fig. 7A); segment 1, 1.6-1.7× longer than wide, and 1.9-2.0 $\times$ longer than segment 2 , which is $1.5-1.6 \times$ longer than wide; segments $3-6$ isodiametric; segment 7 1.3-1.4× wider than long; club $1.9 \times$ longer than wide, as wide as scape at apex.

Pronotum (Fig. 7A) 1.48-1.58 $\times$ wider than long, elytra $1.27-1.31 \times$ longer than wide.

Tarsi with segment $21.2-1.3 \times$ wider than long; segment $31.2-1.3 \times$ wider than long and $1.2-1.3 \times$ wider than segment 2; onychium 1.2-1.3 $\times$ longer than segment 3 .

Male terminalia. Penis (Fig. 8A) in basal half subparallel-sided, in apical half evenly tapered apicad with slightly concave sides, tip bluntly pointed. Tegminal plate short, parameres about as long as half of diameter of ring (Fig. $8 \mathrm{E})$.
Female terminalia. Spermatheca (Fig. 9F) with ramus and nodulus equally large and long, parallel-sided, rounded.

Type material. Holotype: $\widehat{\partial}$, "RSA [South Africa] Limpopo, Awelani lodge E of Masisi, $22^{\circ} 26.047^{\prime} \mathrm{S}, 30^{\circ} 56.495^{\prime} \mathrm{E}, 401 \mathrm{~m}$, 9.xii.2017, R. Borovec lgt." (TMSA). Paratypes: $16 \AA 0$, same data as holotype (RBSC, JSPC, NHMUK, NMPC, MMTI); 1 spec., "S. Afr. [South Africa]; Limpopo Prov., Awelani lodge; E of Masisi; 22.26S-30.56E/10.12.2017; E-Y: 4007, bushveld, leg. Ruth Müller" (TMSA); 14 spec., "S. Afr. [South Africa]; Limpopo Prov., Awelani lodge, 378 m, 22.25S-30.57E/31.1.2017 E-Y: 3992, sifting, leg. Ruth Müller” (TMSA).

Type locality. South Africa, Limpopo, Awelani lodge E of Masisi, $22^{\circ} 26.047^{\prime} \mathrm{S}, 30^{\circ} 56.495^{\prime} \mathrm{E}$.

Derivation of name. Patronymic, dedicated to the name of the locality, where the species was collected.

\section{Afromuelleria baobab sp. $\mathbf{n}$.}

Figs 8B, F, 9B, E, G, 10A-D

ZooBank taxon LSID:

76611AF6-CF15-45A3-BC57-ABFD4E780792

Differential diagnosis. This new species is similar to $A$. awelani sp. n. in its 7-segmented funicle, but distinguishable from it by having a penis with long tip with concave sides and spermatheca with long ramus and short angular nodulus on its opposite side. 


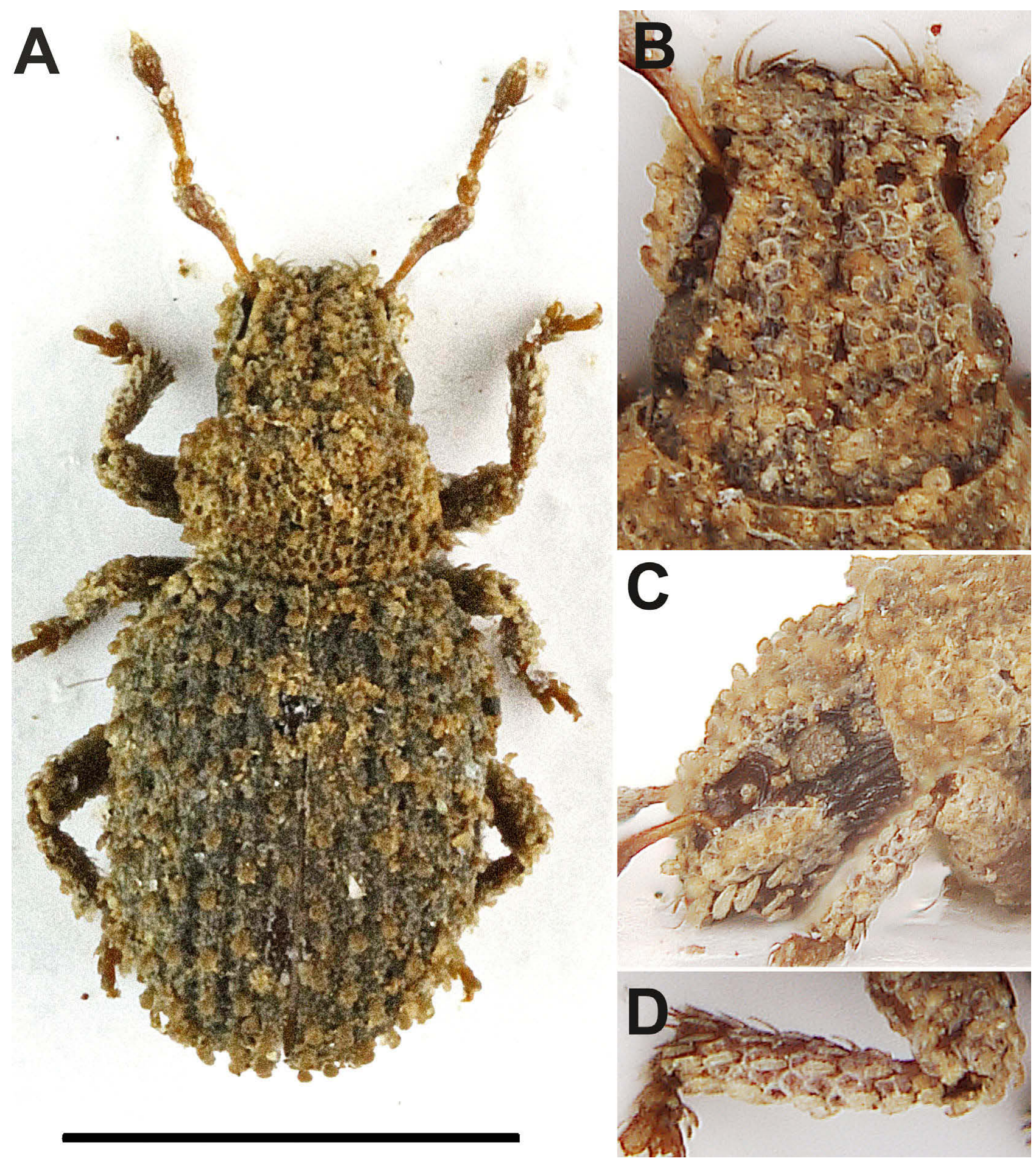

Fig. 10. Afromuelleria baobab sp. n. A - habitus, dorsal view, male; B - rostrum, male, dorsal view; C - rostrum, male, lateral view; D protibia, male. Scale bar: $1 \mathrm{~mm}$.

Description. Body length 1.66-2.14 mm, holotype 1.66 $\mathrm{mm}$. Elytra with conspicuous row of spatulate, semierect setae, slightly longer than half the width of one interstria.

Rostrum (Figs 10B, C) $1.53-1.67 \times$ wider than long, widest at base, evenly tapered apicad with straight sides, at base as wide as head with eyes; eyes weakly projecting beyond outline in dorsal view.

Funicle 7-segmented (Fig. 10A); segment 1 1.7-1.8× longer than wide and 1.9-2.0 $\times$ longer than segment 2 , which is $1.5 \times$ longer than wide; segments $3-6$ isodiamet- ric; segment 7 1.1-1.2 $\times$ wider than long; club twice as long as wide, equally wide as scape at apex.

Pronotum (Fig. 10A) 1.46-1.54× wider than long; elytra $1.32-1.40 \times$ longer than wide.

Tarsi with segment $21.3 \times$ wider than long; segment 3 $1.3-1.4 \times$ wider than long and $1.3 \times$ wider than segment 2 ; onychium 1.4-1.5 $\times$ longer than segment 3 .

Male terminalia. Penis (Fig. 8B) moderately long and slender, widest at base, with slightly concave sides along the whole length, apex distinctly tapered with elongated 

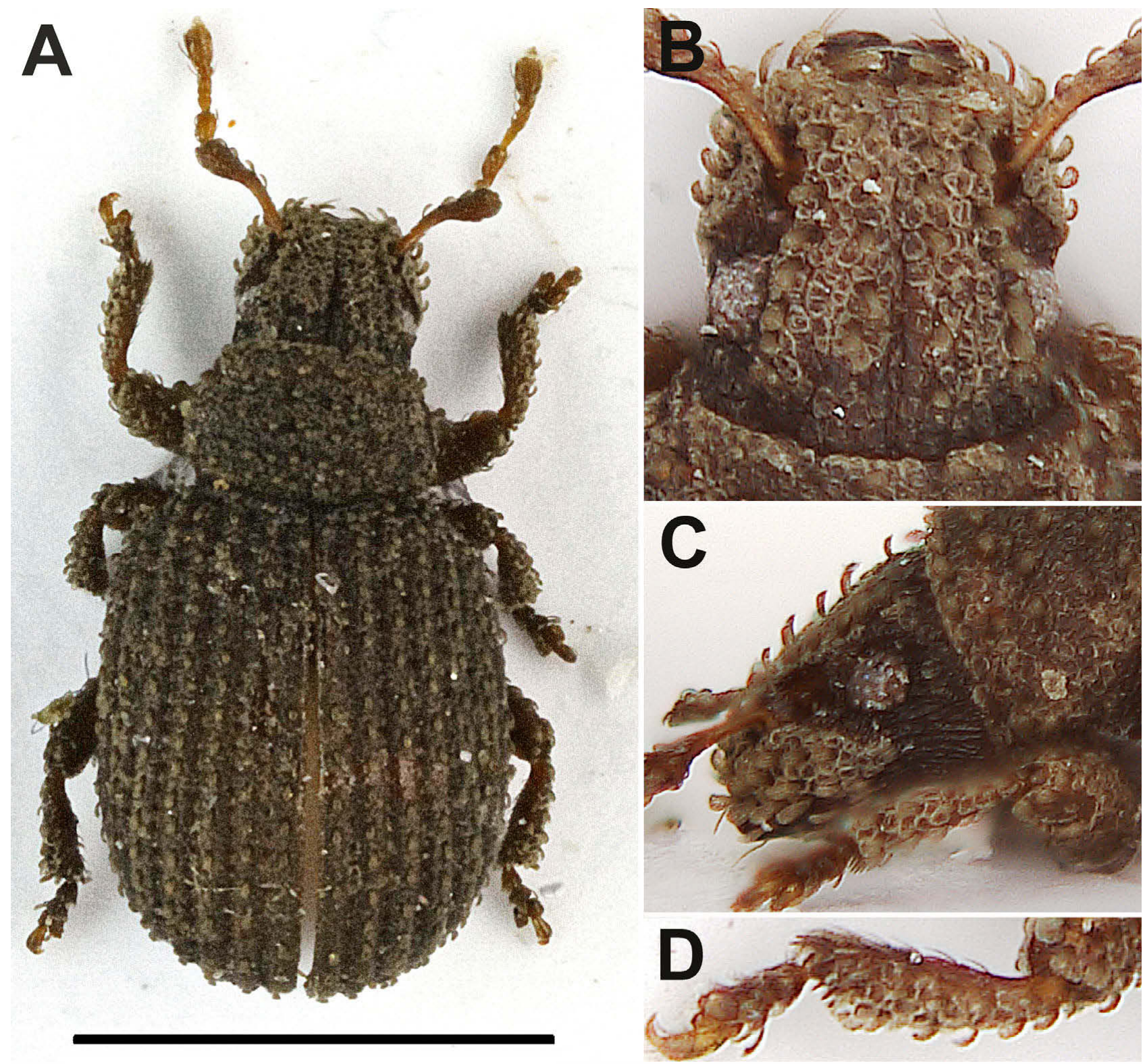

Fig. 11. Afromuelleria limpopo sp. $n$. A - habitus, dorsal view, male; $B$ - rostrum, male, dorsal view; $C$ - rostrum, male, lateral view; $D$ protibia, male. Scale bar: $1 \mathrm{~mm}$.

tip with concave sides. Ring of tegmen slender (Fig. 8F), tegminal plate and parameres long, almost as long as diameter of ring.

Female terminalia. Spermatheca (Fig. 9G) with ramus longer than wide, tapered apicad and nodulus short, angular, staying on its opposite side.

Type material. Holotype: $\hat{\partial}$, "S. Africa, Tvl. [South Africa, Transvaal, Limpopo now], Tshipise, SE 2230 Ca, 3 Aug. 1982, C.M. Engelbrecht/NMBH 11733” (BMSA). Paratypes: 2ð, 1 우, same data as holotype (BMSA).

Additional material examined. 19 , "S. Africa, TVL [South Africa, Transvaal, Limpopo now], Messina, $35 \mathrm{~km}$ on Pontdrift Rd., SE 2229 Bc, 4 Aug. 1982, C.M. Engelbrecht/NMBH 13111" (BMSA).

Type locality. South Africa, Limpopo, Tshipise.

Derivation of name. The name baobab is derivated from the most typical tree in the northern Limpopo, Baobab (Adansonia digitata Linnaeus, 1759, Malvaceae).
Remarks. One female from Messina was not listed among type specimens due to its more slender pronotum and nodulus of spermatheca rounded.

\section{Afromuelleria limpopo sp. $\mathbf{n}$.}

Figs $8 \mathrm{C}, \mathrm{G}, 9 \mathrm{C}, \mathrm{H}, 11 \mathrm{~A}-\mathrm{D}$

ZooBank taxon LSID:

A5815BF2-7B20-4BC5-9000-B62CBAA0C778

Differential diagnosis. 5-segmented funicle and elytra with short, inconspicuous, not very prominent semiappressed setae make this new species easily distinguishable from all other species in the genus.

Description. Body length 1.51-1.81 mm, holotype 1.51 $\mathrm{mm}$. Elytra with inconspicuous row of semiappressed, slender, subspatulate setae, as long as half the width of one interstria. 


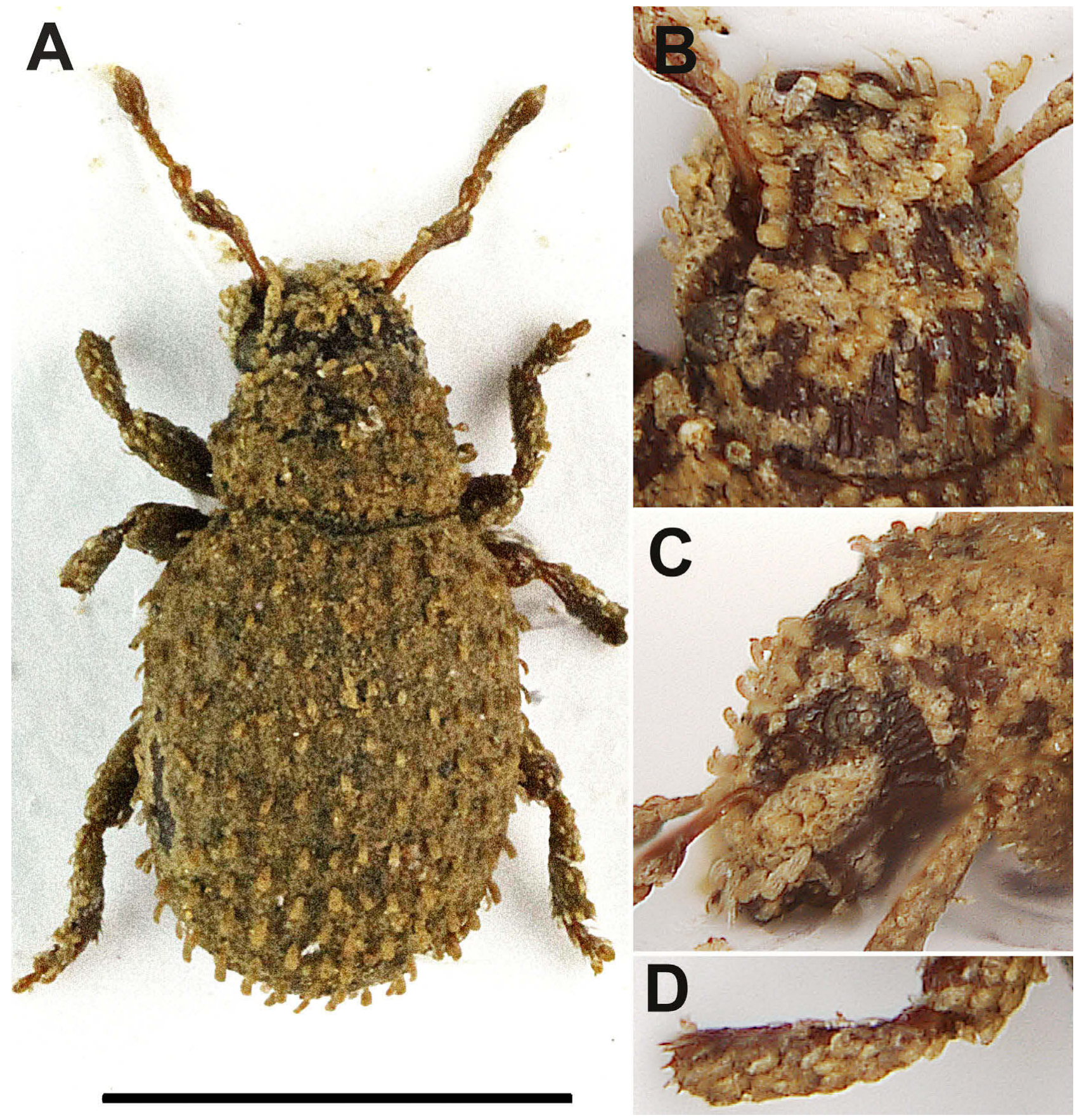

Fig. 12. Afromuelleria venda sp. $\mathrm{n}$. A - habitus, dorsal view, male; B - rostrum, male, dorsal view; C - rostrum, male, lateral view; D protibia, male. Scale bar: $1 \mathrm{~mm}$.

Rostrum (Figs 11B, C) $1.73-1.81 \times$ wider than long, short basal part enlarged anteriad, then evenly tapered apicad with straight sides, at base wider than head with eyes; eyes slightly projecting beyond outline in dorsal view.

Funicle 5-segmented (Fig. 11A); segment 1 1.3-1.4× longer than wide and 1.6-1.7 $\times$ longer than segment 2 , which is $1.4-1.5 \times$ longer than wide; segments 3 and 4 $1.1 \times$ wider than long; segment $51.4-1.5 \times$ wider than long; clubs 1.9-2.0 $\times$ longer than wide, as wide as scape at apex.

Pronotum (Fig. 11A) 1.61-1.76 $\times$ wider than long; elytra $1.24-1.33 \times$ longer than wide.
Tarsi with segment $21.4 \times$ wider than long; segment 3 $1.2-1.3 \times$ wider than long and $1.3 \times$ wider than segment 2 ; onychium $1.2-1.3 \times$ longer than segment 3 .

Male terminalia. Penis (Fig. 8C) widest at base, at midlength distinctly constricted with concave sides, apex subtriangular, tip narrowly rounded. Parameres about as long as half of diameter of ring (Fig. 8G).

Female terminalia. Spermatheca (Fig. 9I) parallel-sided, ramus twice as long and twice as wide as nodulus.

Type material. Holotype: $\delta$, "S. Afr. [South Africa, Limpopo]; Northern Prov., Amatola, Scott farm, 22.56S-29.23E/26.1.1998: E-Y: 3312, ground traps, leg. R. Müller / ground traps with farm. 
banana bait" (TMSA). Paratypes: $1 \curvearrowright, 1$, , same data as holotype (TMSA).

Type locality. South Africa, Limpopo, Amatola, Scott farm, $22^{\circ} 56^{\prime} \mathrm{S}, 29^{\circ} 23^{\prime} \mathrm{E}$.

Derivation of name. Patronymic, dedicated to the province, where this genus and this newly described species were collected.

\section{Afromuelleria venda sp. $\mathbf{n}$.}

Figs 8D, H, 12A-D

ZooBank taxon LSID:

B46F17FD-C87C-450D-9DF9-FC70E9BA934D

Differential diagnosis. $A$. venda sp. $\mathrm{n}$. is easily separated and different from all others by having a 6-segmented funicle.

Description. Body length $1.47 \mathrm{~mm}$. Elytra with conspicuous row of slender subspatulate, semierect setae, slightly longer than half the width of one interstria.

Rostrum (Figs 12B, C) $1.86 \times$ wider than long, widest at base, evenly tapered apicad with straight sides, at base as wide as head with eyes; eyes slightly projecting beyond outline in dorsal view.

Funicle 6-segmented (Fig. 12A); segment $11.8 \times$ longer than wide and $2.2 \times$ longer than segment 2 , which is $1.4 \times$ longer than wide; segment $31.2 \times$ longer than wide; segment $41.1 \times$ longer than wide; segment 5 isodiametric; segment $61.2 \times$ wider than long; club $1.9 \times$ longer than wide, as wide as scape at apex.

Pronotum (Fig. 12A) $1.57 \times$ wider than long; elytra $1.31 \times$ longer than wide.

Tarsi with segment $21.3-1.4 \times$ wider than long; segment $31.4-1.5 \times$ wider than long and $1.2-1.3 \times$ wider than segment 2 ; onychium $1.2-1.3 \times$ longer than segment 3 .

Male terminalia. Penis (Fig. 8D) widest at base, evenly tapered apicad, apex subtriangular. Ring of tegmen slender (Fig. 8H), tegminal plate long, almost as long as diameter of ring, parameres shorter than plate.

Female terminalia. Unknown.

Type material. Holotype: $1 \delta^{\Uparrow}$, "S. Africa, Tvl. [South Africa, Transvaal, Limpopo now], Mopane, Se2229 Db, 3 Aug. 1982, C. M. Engelbrecht / NMBH 11725" (BMSA).

Type locality. South Africa, Limpopo, Mopane.

Derivation of name. The name venda is dedicated to the Venda people, Southern African people living mostly near South African - Zimbabwean border, in the same region as this genus and newly described species occur.

\section{Key to the species of Afromuelleria gen. $\mathbf{n}$.}

1 Funicle 5-segmented, elytra with inconspicuous row of semiappressed setae, as long as half width of one interstria (Fig. 11A). Penis distinctly constricted at midlength (Fig. 8C) ....... A. limpopo sp. n.

Funicle 6- or 7-segmented, elytra with conspicuous row of semierect setae, slightly longer than half width of one interstria (Figs 7A, 10A, 12A). Penis not constricted at most with slightly concave sides (Figs 8A, B, D)

2 Funicle 6-segmented, elytra with raised slender, subspatulate setae (Fig. 12A) ............................................ venda sp. n.

- Funicle 7-segmented, elytra with raised wide, spatulate setae (Figs 7A, 10A)...
3 Rostrum widest before base, wider than head with eyes (Fig. 7B). Eyes hardly projecting beyond outline in dorsal view (Fig. 7A). Penis with shortly pointed tip (Fig. 8A). Spermatheca with ramus and nodulus equally large and long, and parallel to each other (Fig. 9F) ...................... awelani sp. n.

- Rostrum widest at base, as wide as head with eyes, latter slightly projecting beyond outline in dorsal view (Fig. 10A). Penis with tip distinctly elongate with concave sides (Fig. $8 \mathrm{~B})$. Spermatheca with long ramus and nodulus short, angular, on its opposite side (Fig. 9G)................. A. baobab sp. n.

ACKNOWLEDGEMENTS. We thank B. Muller (BMSA) and R. Müller (TMSA) for the loan of specimens. The first author thanks R. Müller for guiding the Limpopo field trip, which allowed us to collect material of the type species. Special thanks to J. Cooter (Oxford, UK) for linguistic help on the manuscript. We thank two anonymous reviewers for valuable critical comments. The first author was supported by grant CIGA No. 20174313 of the Czech University of Life Sciences Prague, Faculty of Forestry and Wood Sciences.

\section{REFERENCES}

Borovec R. \& Meregalli M. 2013: Soil insect research in South Africa. 1. A new genus of terricolous weevils with four new species from the Richtersveld National Park (Coleoptera: Curculionidae: Entiminae: Trachyphloeini). - Zootaxa 3646: 501-515.

Borovec R. \& Oberprieler R. 2013: Afrophloeus, a new genus of African weevils of the tribe Embrithini (Coleoptera: Curculionidae: Entiminae), with description of a new species and notes on the composition of Embrithini. - Zootaxa 3693: 365-378.

Borovec R. \& Skuhrovec J. 2017a: Systematic position of the Afrotropical species described in Trachyphloeini (Coleoptera: Curculionidae: Entiminae). — Zootaxa 4344: 522-540.

Borovec R. \& Skuhrovec J. 2017b: Epistomius, a new genus of African forest litter Trachyphloeini, with description of seven new species (Coleoptera: Curculionidae: Entiminae). - Acta Entomol. Mus. Nat. Pragae 57: 645-676.

Borovec R. \& Skuhrovec J. 2018: Revision of the species related to Lalagetes subfasciatus Boheman and transfer of remaining Lalagetes species to other genera of Embrithini (Coleoptera: Curculionidae: Entiminae). - Zootaxa 4374: 71-90.

Borovec R. Colonnelli E. \& Osella G. 2009: On the South African genus Heisonyx (Coleoptera: Curculionidae: Entiminae). - Acta Entomol. Mus. Nat. Pragae 49: 841-860.

Borovec R. Colonnelli E. \& Osella G. 2014: Revision of the South African genus Porpacus (Coleoptera: Curculionidae: Entiminae: Embrithini). - Klapalekiana 50: 7-44.

Del Río M.G., Rodriguero M.S., Confalonieri V.A. \& Lanteri A.A. 2018: Molecular and morphological phylogenetic analysis of Naupactus Dejean (Curculionidae: Entiminae) and allied genera: The dilemma of classification. - Diversity 10: 1-16.

FÅnRAeus O.I. 1871: Coleoptera Caffrariae, annis 1838-1845 a J.A. Wahlberg collecta. Curculionides. - Öfvers. Kongl. Vetenskaps-Akad. Förhandl. (Stockholm) 28: 3-69.

GunN M. \& CodD L.E. 1981: Botanical Exploration of Southern Africa. A.A. Balkema, Cape Town, 400 pp.

Hendrych R. 1984: Phytogeography. State Pedagogical Publishers, Praha, 220 pp. [in Czech].

Marshall G.A.K. 1923: On new Curculionidae from South Africa. - Ann. Mag. Nat. Hist. (Ser. 9) 11: 531-553.

Marshall G.A.K. 1955: New South African Curculionidae (Col.). - Ann. Mag. Nat. Hist. (Ser. 12) 8: 1-24. 
OBERPRIELER R.G. 1988: Revision of the Tanyrhynchini of continental Africa (Coleoptera: Curculionidae). I. Introduction and review of the genera, revision of the genus Brachytrachelus Schönherr and description of Afroleptops gen. nov. - Entomol. Mem. Dep. Agric. Water Sup. Rep. S. Afr. 71: 1-5.

OBerprieler R.G. 1995: Systematic position and composition of the tribes Tanyrhynchini and Myorhinini (Coleoptera: Curculionidae). - Mem. Entomol. Soc. Wash. 14: 155-167.

Oberprieler R.G., Marvaldi A.E. \& Anderson R.S. 2007: Weevils, weevils, weevils everywhere. - Zootaxa 1668: 491-520.

Oberprieler R.G., Anderson R.S. \& Marvaldi A.E. 2014: 3. Curculionoidea Latreille, 1802: Introduction, Phylogeny. In Leschen R.A.B. \& Beutel R.G. (eds): Handbook of Zoology, Arthropoda: Insecta; Coleoptera, Beetles. Vol. 3: Morphology and Systematics (Phytophaga). Walter de Gruyter, Berlin/Boston, pp. 285-300.

SchoenherR C.J. 1842: Genera et species curculionidum, cum synonymia hujus familiae. Species novae aut hactenus minus cognitae, descriptionibus a Dom. L. Gyllenhal, C.H. Boheman, O.J. Fahraeus et entomologis aliis, illustratae. Tomus septimus. Pars prima. Roret, Paris, vi +479 pp.

Schoenherr C.J. 1843: Genera et species curculionidum, cum synonymia hujus familiae. Species novae aut hactenus minus cognitae, descriptionibus a Dom. L. Gyllenhal, C.H. Boheman, O.J. Fahraeus et entomologis aliis, illustratae. Tomus septimus. Pars secunda. Roret, Paris, Fleischer, Lipsiae, viii +461 pp.

SCHOENHERR C.J. 1845: Genera et species curculionidum, cum synonymia hujus familiae. Species novae aut hactenus minus cognitae, descriptionibus a Dom. L. Gyllenhal, C.H. Boheman, O.J. Fahraeus et entomologiis aliis, illustratae. Tomus octavus. Pars secunda. Roret, Paris, Fleischer, Lipsiae, viii +504 pp.

SCHOENHERR C.J. 1847: Mantissa secunda familiae curculionidum seudescriptiones novorum quorundam generum curculionidum. Holrniae, pp. 1-86.

Voss E. 1959: Unbekannte Curculioniden aus der orientalischen und äthiopischen Region (152. Beitrag zur Kenntnis der Curculioniden). - Entomol. Arb. Mus. G. Frey 10: 407-414.

Voss E. 1974: Chapter VI. Coleoptera Curculionidae partim. In Hanström B., Brinck P. \& Rudebeck G. (eds): South African Animal Life, Results of the Lund University Expedition in 1950-1951. Vol. 15. Almqvist and Wiksell, Stockholm, pp. 395-479.

Received June 14, 2018; revised and accepted October 1, 2018 Published online December 4, 2018 